\title{
PEMANFAATAN MEDIA SOSIAL SEBAGAI STRATEGI UMKM DALAM MENINGKATKAN PENJUALAN DI MASA PANDEMI COVID 19
}

\author{
${ }^{1 *}$ Surenggono, ${ }^{2}$ Atty Erdiana, ${ }^{3}$ Siti Djamilah \\ Universitas Wijaya Kusuma Surabaya, Jawa Timur, Indonesia \\ Email : * natanaelsurenggono@gmail.com \\ Manuskrip: Juni -2021; Ditinjau: Juni -2021; Diterima: Juli -2021; \\ Online: Juli-2021; Diterbitkan: Juli-2021
}

\begin{abstract}
ABSTRAK
Pandemi covid-19 berdampak pada hampir semua sektor kehidupan, tak terkecuali aktivitas perdagangan yang dilakukan oleh Usaha Mikro Kecil Menengah (UMKM). Oleh karena itu UMKM perlu segera menyesuaikan cara bisnisnya dengan menggunakan cara yang sesuai dengan situasi kondisi saat ini. Tujuan kegiatan pengabdian kepada masyarakat ini adalah membantu para pelaku usaha yang tergabung dalam Asosiasi Usaha Kecil Menengah Amangtiwi Malang menghadapi lesunya perekonomian dan diharapkan dapat menunjang manajemen pemasarannya di era digital guna meningkatkan penjualan.

Tahapan pendampingan dimulai dari pemberian materi tentang pemasaran modern dan pengenalan beberapa aplikasi di media sosial, yang meliputi: konsep pemasaran modern (segmentasi, targeting, positioning, marketing mix); Aplikasi WhatsApp; Aplikasi Facebook; dan Aplikasi Instagram. Tahapan berikutnya para anggota UMKM yang tergabung di Asosiasi tersebut didampingi untuk membuat dan dapat mengoperasikan aplikasi guna mendukung kegiatan usaha mereka.

Perubahan cara memasarkan produk yang digunakan anggota UMKM dengan menggunakan media sosial ini memberikan manfaat dan hasil yang lebih baik bagi anggota kelompok Asosiasi UKM Amangtiwi Malang di saat Pandemi ini maupun di masa yang akan datang yaitu berupa semakin dikenalnya produk-produk yang ditawarkan mereka dan naiknya penjualan produk tersebut, karena mereka telah memasarkan produknya secara online dan memiliki akses yang lebih luas (tidak hanya di Kota Malang saja).
\end{abstract}

\section{Kata Kunci: Pemasaran, Media Sosial, Penjualan, UMKM}

\section{PENDAHULUAN}

Pandemi covid-19 menyebabkan kecemasan bagi semua orang di segala penjuru dunia, tak terkecuali penduduk Indonesia. Kecemasan terjadi hampir disemua sektor kehidupan yang terdampak, yaitu sektor ekonomi, perdagangan, transportasi dan lain-lain. Karena pandemi inilah maka seluruh lapisan masyarakat terkena dampaknya, rutinitas yang semula dijalani akhirnya harus disesuaikan kalau ingin tetap survive. 
Dampak penyebaran virus covid-19 sangat berpengaruh di sektor ekonomi, hal ini akhirnya yang menyebabkan persaingan bisnis dan kondisi pasar menjadi lesu. Asosiasi Penyelenggara Jasa Internet Indonesia dan Teknopreneur (APJII) mengatakan bahwa selama pandemi covid hanya 48,9\% stratup mengaku bisa bertahan lebih dari 1 tahun, sedangkan $51,1 \%$ sulit mempertahankan bisnisnya (APJII, 2020). Hal ini disebabkan lesunya daya beli konsumen akibat krisis kesehatan yang terjadi karena adanya virus covid-19. Kondisi ini juga dialami oleh hampir semua Usaha Mikro Kecil Menengah (UMKM), dimana saat ini mereka banyak mengalami penurunan penjualan. Kalau mereka tidak tanggap dan tidak segera bangkit maka bisa dipastikan bisnisnya tidak akan bertahan lama.

Pandemi yang terjadi saat ini secara tidak langsung menjadi stimulus yang baik pada perkembangan bisnis online dan mengharuskan para pengusaha untuk cepat beradaptasi agar kegiatan usahanya tetap berjalan normal. Anggota Asosiasi Usaha Kecil Menengah Amangtiwi yang berlokasi di Sawojajar Malang juga perlu merubah kegiatan jual beli yang konvensional dengan cara penjualan yang lebih modern yaitu penjualan online. Melalui kegiatan tersebut diharapkan dapat memperluas wilayah pemasaran dan dapat meningkatan penjualan anggotanya. Para anggota asosiasi ini perlu mendapatkan pendampingan untuk merubah cara penjualannya yang saat ini masih konvensional menjadi penjualan yang berbasic digital atau dengan kata lain melakukan perdagangan elektronik (e-commerce). Ecommerce adalah saluran online melalui komputer, dapat digunakan pebisnis menjalankan aktifitas bisnisnya juga konsumen untuk mendapatkan informasi terkait hal tersebut yang diawali dengan proses memberi jasa informasi pada konsumen dalam penentuan pilihan (Armstrong and Kotler, 2015).

Berdasar penjelasan di atas, maka perlulah kami para akademisi untuk terlibat langsung pada masyarakat pelaku usaha yang terdampak aktivitasnya akibat pandemi Covid-19 ini melalui kegiatan Tridarma Perguruan Tinggi dalam bentuk pendampingan yang merupakan implementasi dari kegiatan pengabdian masyarakat. Adapun tujuan dari kegiatan pendampingan ini adalah membantu para pelaku usaha khususnya pelaku usaha yang tergabung dalam Asosiasi Usaha Kecil Menengah Amangtiwi Malang dalam menghadapi lesunya perekonomian selama masa Pademi Covid-19 serta diharapkan dapat menunjang kegiatan pemasarannya di era digital guna meningkatkan penjualan.

\section{METODE PELAKSANAAN KEGIATAN}

Kegiatan pengabdian masyarakat ini diawali dengan melakukan survey pendahuluan ke obyek kegiatan yaitu Asosiasi Usaha Kecil Menengah Amangtiwi yang beralamat di Jl. Kapi Minda Raya 10.A/24 Sawojajar 2 Malang. Pada tahap ini selain meminta ijin pada pimpinan Asosiasi, tim Pengabdi juga mengumpulkan informasi terkait dengan aktivitas-aktivitas yang dilakukan oleh pelaku usaha yang tergabung dalam asosiasi ini, khususnya yang berkaitan dengan aktivitas pemasarannya.

Tahap berikutnya dibuatlah jadwal pendampingan. Saat pendampingan dimulai dari pemberian materi tentang konsep pemasaran modern, yaitu bagaimana 
pelaku usaha dalam era digital ini mampu untuk melakukan segmentasi pasar, menentukan targeting dan menetapkan positioning atas produk yang dihasilkannya, pelaku usaha juga harus selalu mengamati perubahan perilaku dari konsumennya dan mengenalkan beberapa aplikasi dalam media sosial (Whats App, Facebook dan Instagram)yang bisa dijadikan sebagai media penjualan mereka, dimana hal ini menjadi target Pengabdi di tahun pertama, dilanjutkan dengan mendampingi cara penerapan aplikasi tersebut.

Pada pertemuan-pertemuan selanjutnya dilakukan monitoring penggunaan aplikasi-aplikasi tersebut. Setelah pendampingan ini, diharapkan ada hasil yang akan didapat oleh anggota kelompok Asosiasi UKM Amangtiwi, yaitu berupa semakin dikenalnya produk-produk yang ditawarkan dan naiknya penjualan produk tersebut.

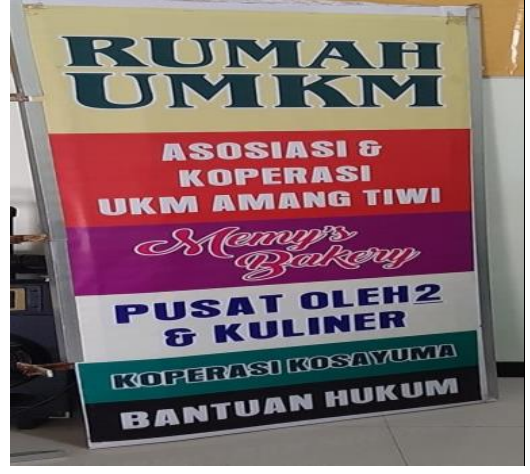

Gambar 1. Asosiasi UKM Amangtiwi

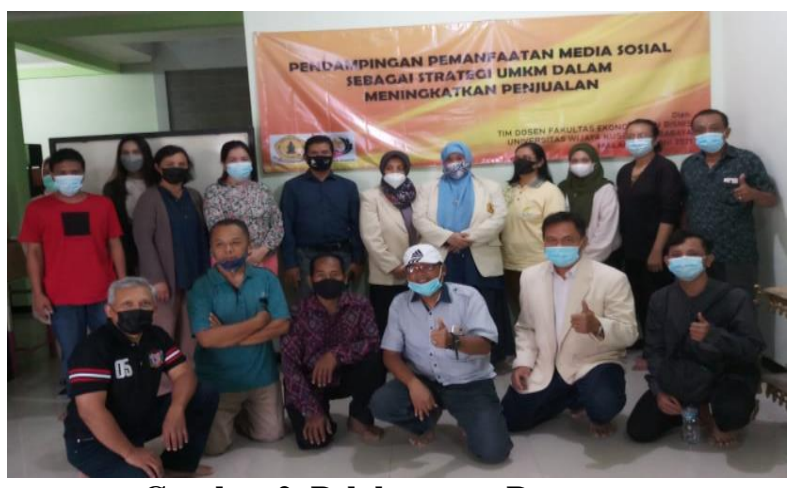

Gambar 2. Pelaksanaan Penmas

\section{HASIL DAN PEMBAHASAN}

Kegiatan pengabdian masyarakat di Asosiasi Usaha Kecil Menengah Amangtiwi yang berlokasi di jalan Kapi Minda Raya 10.A/24 Sawojajar 2 Malang dilaksanakan selama 4 bulan yang dimulai pada bulan Maret 2021. Kegiatan pengabdian masyarakat ini dilaksanakan biasanya di hari Sabtu dan berlangsung mulai pukul 12.30 WIB karena menyesuaikan dengan waktu luang yang dimiliki oleh peserta. Mengingat saat ini masih dalam situasi pandemi dan adanya pembatasan kegiatan masyarakat di kota Malang, maka peserta yang hadir pada acara ini dibatasi hanya sebanyak 20 orang. Dalam pelaksanaan acara ini tetap memperhatikan dan menerapkan protokol kesehatan sesuai anjuran pemerintah (memakai masker, menjaga jarak dan mencuci tangan).

Pendampingan dimulai dengan pemberian materi tentang konsep pemasaran modern dan pengenalan beberapa aplikasi yang ada di media sosial. Pada saat pemberian materi awal berupa penjelasan tentang ecommerce dan e marketing, kemudian tentang media sosial, manfaat media sosial dan proses pemasaran. Proses pemasaran berupa identifikasi kebutuhan dan keinginan pasar, segmentasi, targeting dan positioning, bauran pemasaran, bauran pemasaran elektronik dan kepuasan konsumen. Selain itu pada pendampingan periode ini peserta dikenalkan dengan beberapa aplikasi yang ada di media sosial, yaitu: Aplikasi WhatsApp, 
Aplikasi Facebook dan Aplikasi Instagram yang bisa mereka gunakan untuk menginformasikan produk-produk yang mereka jual.

Kegiatan pendampingan ini tidak hanya dilakukan satu hari saja, tetapi kegiatan ini berlanjut sesuai dengan permintaan peserta disaat mereka membutuhkan untuk awal mengoperasikan aplikasi yang akan digunakan dan juga saat evaluasi kegiatan pengabdian masyarakat. Pendampingan berlangsung selama 4 bulan sehingga Pengabdi mempunyai target di tahun 2021 mereka sudah mampu menjalankan aplikasi tersebut dengan baik dengan mendasarkan pada konsep pemasaran saat mereka menginformasikan produknya tersebut. Disamping itu pada pertemuan-pertemuan selanjutnya Pengabdi melakukan monitoring penggunaan aplikasi-aplikasi tersebut.

Kegiatan pendampingan ini diharapkan memberikan manfaat dan hasil yang lebih baik bagi anggota kelompok Asosiasi UKM Amangtiwi, yaitu berupa semakin dikenalnya produk-produk yang ditawarkan, karena dengan melakukan pemasaran melalui media sosial jangkauan wilayah yang dapat diakses lebih luas lagi jadi tidak terbatas di wilayah lokal saja. Selain hal tersebut para pelaku usaha ketika menginformasikan produknya akan bisa lebih tepat baik cara ataupun sasaran pasar yang akan dituju karena mereka juga sudah dibekali dengan pengetahuan tentang konsep pemasaran modern. Dengan adanya perubahan pola pikir mereka dari cara penjualan konvensional berubah menjadi penjualan dengan tehnologi kekinian, maka diharapankan akan membawa dampak positif bagi usaha mereka yaitu naiknya penjualan produknya, sehingga hal ini akan membantu mereka untuk meningkatkan pendapatannya baik di masa pandemi ini maupun masa-masa yang akan datang

\section{KESIMPULAN}

Kegiatan pengabdian masyarakat ini berupa Pendampingan Pemanfaatan Media Sosial Sebagai Strategi UMKM Dalam Meningkatkan Penjualan. Kegiatan ini diikuti oleh 20 pelaku usaha yang berada dibawah naungan Asosiasi Usaha Kecil Menengah Amangtiwi yang beralamatkan di jalan Kapi Minda Raya 10.A/24 Sawojajar 2 Malang.

Kegiatan ini bertujuan untuk membantu para pengusaha Asosiasi Usaha Kecil Menengah Amangtiwi Malang dalam menghadapi lesunya perekonomian selama masa Pademi Covid-19 dengan cara memasarkan produknya melalui media sosial yaitu aplikasi Whats App, Facebook dan Instagram dengan mengimplementasikan konsep pemasaran modern.

Kegiatan pendampingan ini diharapkan akan memberikan manfaat dan hasil yang lebih baik bagi anggota kelompok Asosiasi UKM Amangtiwi, yaitu berupa semakin dikenalnya produk-produk yang ditawarkan dan naiknya penjualan produk tersebut, karena mereka telah memasarkan produknya secara online dan memiliki akses yang lebih luas.

Harapan Pengabdi terhadap para pengusaha UMKM yang tergabung dalam Asosiasi Usaha Kecil Menengah Amangtiwi hendaknya selalu tanggap terhadap 
perubahan tehnologi dan selalu melakukan penyesuaian untuk mendukung usahanya., selain itu hendaknya para pelaku usaha selalu mengamati perubahan perilaku dari konsumennya sehingga pelaku usaha akan lebih mudah untuk memasarkan produk yang dihasilkan.

Kami sebagai tim Pengabdi mengucapkan banyak terimakasih untuk LPPM UWKS, Pimpinan Dekanat dan Program Studi di Fakultas Ekonomi dan Bisnis Universitas Wijaya Kusuma Surabaya yang telah mendukung kami untuk menyelesaikan kegiatan Tridarma Perguruan Tinggi ini. Tak lupa pula kami juga mengucapkan terima kasih kepada pimpinan Asosiasi Usaha Kecil Menengah Amangtiwi yang telah memberikan dukungan dan kesempatan pada Tim untuk melakukan kegiatan ini.

\section{DAFTAR PUSTAKA}

Ajimat, A., et al. (2020). Berwirausaha Memanfaatkan Media Sosial Pada Daerah Sepatan. ADI Pengabdian Kepada Masyarakat, 1(1), 69-76.

Armstrong dan Kotler, Philip, 2015. Marketing an Introducing. Twelfth edition, England: Pearson Education, Inc

Asosiasi Penyelenggara Jasa Internet Indonesia (APJII), 2020, Buletin APJII edisi 71 - september 2020

https://marketingcraft.getcraft.com/id-articles/memahami-jenis-jenis-media-sosial 